\title{
Relationship between mains costs and voltage switches
}

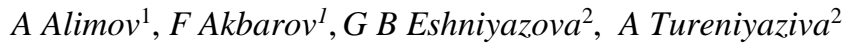 \\ ${ }^{1}$ Tashkent State Technical University named by Islam Karimov, Tashkent, Uzbekistan \\ ${ }^{2}$ Nukus Branch of Tashkent University of Information Technologies.
}

\begin{abstract}
The article deals with the issues of interconnection of network costs and power quality, in particular voltage deviations. The graphs of the distribution of voltage deviations for electrical receivers are given for two calculated load modes the highest $(100 \%)$ and the lowest $(25 \%)$, corresponding to the choice of wires of 10 and $0.38 \mathrm{kV}$ overhead lines for economic loads and voltage stabilization on $10 \mathrm{kV}$ buses of $35 / 10 \mathrm{kV}$ RTP at the level of $+5 \%$.
\end{abstract}

Keywords. Power quality, voltage, deviations, range, modes, costs, transformer

With the given characteristics of the technical means used in the networks, the voltage quality depends on the costs incurred, therefore, it is possible to establish probabilistic links between the technical and economic indicators of the network and the permissible voltage deviations. These dependencies make it possible to objectively assess the national economic costs necessary to ensure certain voltage deviations. On the other hand, they should be used to solve the problem of optimizing power quality indicators [1-8].

When establishing the probabilistic dependences of the technical and economic indicators of the network on the permissible voltage deviations, it is necessary to proceed from the most economical solutions. Such solutions, as you know, are provided by the choice of overhead line wire crosssections according to economic loads. Therefore, when constructing the initial models, one should use overhead lines of 10 and $0,38 \mathrm{kV}$, the cross-sections of the wires in which are selected according to economic loads [9-14].

Distributions are rather accurately described by truncated normal curves

$$
f\left(\Delta U_{3}\right)=\frac{1}{A_{3} \sigma_{3} \sqrt{2 \pi}} e^{-\frac{\left(\Delta U_{3}-\Delta \bar{U}_{3}\right)^{2}}{2 \sigma_{3}^{2}}}
$$

wherein $\Delta U_{\ni}>0$.

The parameters of the distribution curves have the following meanings

$$
\begin{gathered}
\Delta \bar{U}_{10 y}=4,51 \% ; \sigma_{10 y}=2,25 \% ; \\
A_{10 y}=1-\int_{-\infty}^{0} f\left(\Delta U_{10 y}\right) d \Delta U_{10 y}=0,977 ; \\
\Delta \bar{U}_{0.38 y}=3,5 \% ; \sigma_{0.38 v}=4.5 \% ;
\end{gathered}
$$

The indicated distributions were taken as the initial ones when establishing the fluctuations of the technical and economic indicators of the networks and the permissible voltage deviations [15-17].

The selection of wire cross-sections in electrical networks in terms of economic loads corresponds to the above reduced costs and certain (let's call them economic) limits of voltage deviations from consumers.

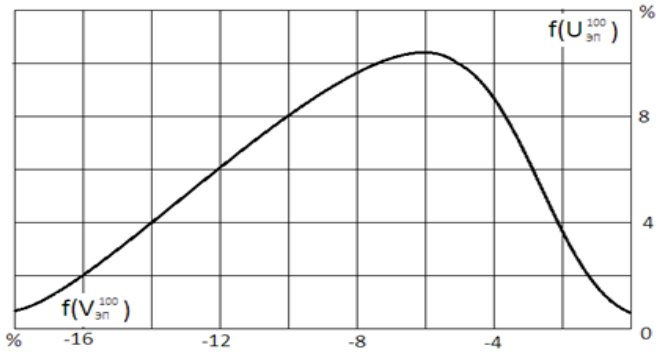

Fig. 1. Distribution of voltage deviations at power consumers in the highest load mode.

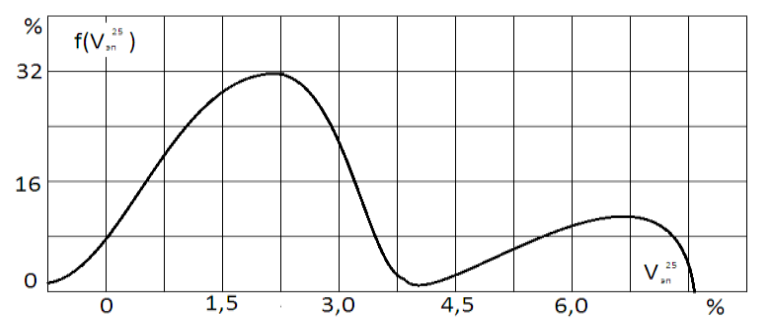

Fig. 2. Distribution of voltage deviations at power consumers in the lowest load mode.

In fig. Figures 1 and 2 show the distributions of voltage deviations for electrical receivers for two calculated load modes - the highest $(100 \%)$ and the lowest (25\%), corresponding to the choice of wires of 10 and $0,38 \mathrm{kV}$ overhead lines for economic loads and voltage stabilization on $10 \mathrm{kV}$ buses RTP $35 / 10 \mathrm{kV}$ at $+5 \%$ [1824].

The technique for constructing these distributions is reduced to finding the laws of distribution of the sum of 
two independent random variables: $V_{\text {shol }}$ (voltage deviation on the buses $0,4 \mathrm{kV}$ for $10 / 0,4 \mathrm{kV}$ transformer substations) and $\Delta \mathrm{U}_{\mathrm{o}}, \mathrm{z}_{8 \mathrm{e}}$ (voltage loss of $0,38 \mathrm{kV}$ lines).

$$
F\left(V_{g n}^{100}\right)=\iint_{(D)} f\left(V_{\text {II } 0,4}\right) f\left(-\Delta U_{0.383}\right) d V_{\text {II } 0,4} d \Delta U_{0.383}
$$

where D- region of integration determined by the range of variation of values $V_{m} o$, each zone of transformer additions, and direct $\mathrm{V}_{2 \pi}^{100}=\mathrm{V}_{\amalg, 0,4}+\left(-\mathrm{U}_{0,383}\right) ; /\left(\mathrm{V}_{\amalg, 0,4}\right)$ - the distribution law of voltage deviations on the $0.4 \mathrm{kV}$ TP buses of each zone of the transformer additions $(0 ; 2,5 ; 5 \%$, etc.) [25-31].

Calculations have shown that a change in the accepted cost of $10 / 0,4 \mathrm{kV}$ regulated transformers within a relatively wide range has little effect on the total reduced costs, and only noticeably changes the metal consumption and the number of regulated transformers [32-35].

Table 1.

Technical and economic indicators of networks depending on permissible voltages

\begin{tabular}{|c|c|c|c|c|c|c|}
\hline $\begin{array}{l}\text { Calculated } \\
\text { limits of } \\
\text { permissible } \\
\text { voltage } \\
\text { deviations }\end{array}$ & \multicolumn{2}{|c|}{$\begin{array}{c}\text { Relative rise } \\
\text { in price }(\%) \\
\text { of the } \\
\text { variable part } \\
\text { of the reduced } \\
\text { costs at the } \\
\text { stage of } \\
\text { unregulated } \\
\text { transformer } \\
\text { taps }\end{array}$} & \multicolumn{2}{|c|}{$\begin{array}{c}\text { Additional } \\
\text { metal costs (\%) } \\
\text { at the step of } \\
\text { unregulated } \\
\text { transformer taps }\end{array}$} & \multicolumn{2}{|c|}{$\begin{array}{l}\text { The number of } \\
\text { regulated } \\
\text { transformers } \\
\text { (in \% of the } \\
\text { total number) at } \\
\text { the stage of } \\
\text { unregulated } \\
\text { taps }\end{array}$} \\
\hline$\%$ & $2,5 \%$ & $5 \%$ & $2,5 \%$ & $5 \%$ & $2,5 \%$ & $5 \%$ \\
\hline \multicolumn{7}{|c|}{ Voltage stabilization $(+5 \%)$ at $35 / 10 \mathrm{kV}$ substation } \\
\hline$-15 \div+7,5$ & - & - & - & - & - & - \\
\hline$-10 \div+7,5$ & 2,5 & 4 & 9 & 13,5 & - & - \\
\hline \pm 7 & 7,5 & 16 & 18 & 25 & - & 20 \\
\hline \pm 5 & 22 & 22 & 25 & 20,5 & 56 & 62 \\
\hline \multicolumn{7}{|c|}{ Counter regulation (from 0 to $+5 \%$ ) at $35 / 10 \mathrm{kV}$ substation } \\
\hline$-10 \div+7,5$ & - & 1 & - & 1,5 & - & - \\
\hline \pm 7 & 2 & 4 & 2 & 5 & - & - \\
\hline \pm 5 & 5 & 9 & 11 & 20 & - & - \\
\hline
\end{tabular}

The need for transformers with on-load tap-changers can be reduced by using booster transformers (VDT). The efficiency of their application depends on the number of $10 / 0,4 \mathrm{kV}$ transformers with on-load tap-changers in the network and its configuration. Calculations have shown that at the accepted costs, the use of RCCB is economically justified if or it is possible to replace $8-10 \quad 10 / 0,4 \mathrm{kV}$ transformers with OLTC. It is possible to use RCCBs to ensure the permissible limits of voltage deviations at consumers with an increase in the calculated (design) loads of the networks. In newly constructed networks, they should be rarely used [36-38].

The technical and economic indicators of distribution networks (reduced costs, consumption of conductive metal and the required number of adjustable transformers 10/0,4 $\mathrm{kV}$ ) at some limits of voltage tolerances, calculated according to the above method, are given in Table. $2 \%$ [39-40].

The results obtained make it possible, in particular, to assess the effectiveness of the use of counter voltage regulation on the $35 / 10 \mathrm{kV}$ RTP, the expediency of splitting the steps of the regulating branches of transformers, etc. 25 it can be seen that the implementation of counter voltage regulation at the RTP $35 / 10 \mathrm{kV}$ in the range from 0 to $+5 \%$ allows you to select the cross-sections of wires in the 10 and $0,38 \mathrm{kV}$ overhead lines according to economic loads, ensuring minimal costs for the construction of these lines. The greatest limits of voltage deviations for electrical receivers will practically not exceed $-10 \div+7,5 \%$. The use of counter voltage regulation, in comparison with stabilization, significantly reduces the cost of the network and when going from the normalized voltage deviations $-10 \div+7,5 \%$ to $\pm 5 \%$. In the presence of counter regulation, it is possible to practically abandon the use of distribution transformers with on-load tapchangers and RCCBs.

\section{References}

1. TAN Mu-zi, LI Xiao-song, Calculation of Theoretical Line Loss for Rural Low-Voltage Distribution Networks under Unbalanced Three-Phase Loads based on Time Segment, Journal of Hunan Institute of Science and Technology (Natural Sciences), 2015, (1)

2. Houdek V., Sojka J., Rusek S., Gono R.: Backup alternatives for $110 \mathrm{kV}$ lines. International Scientific Conference Electric Power Engineering 2012. May 2021, Brno Czech Republic ISBN 978-80-214-4514-7 (str. 929934).

3. Carpaneto, E.; Chicco, G.; Sumaili Akilimali, J. Loss partitioning and loss allocation in three-phase radial distribution systems with distributed generation. IEEE Trans. Power Syst. 2008, 23, 1039-1049.

4. Atanasovski, M.; Taleski, R. Energy summation method for loss allocation in radial distribution networks with DG. IEEE Trans. Power Syst. 2012, 27, 1433-1440.

5. I.Rakhmonov, A.Berdishev, N.Niyozov, A.Muratov and U.Khaliknazarov. Development of a scheme for generating the predicted value of specific electricity consumption // CONMECHYDRO - 2020. IOP Conf. Series: Materials Science and Engineering. $883 \quad$ (2020) 012103. doi:10.1088/1757-899X/883/1/012103

6. F.A.Hoshimov, I.I.Bakhadirov, M.S.Kurbanbayeva, N.A.Aytbayev. Development of specific standards of energy consumption by types of produced products of the spinning product // RSES 2020. E3S Web of Conferences. 216 (2020) 01169. https://doi.org/10.1051/e3sconf/202021601169
7. F.A.Hoshimov,
I.I.Bakhadirov,
A.A.Alimov, M.T.Erejepov. Forecasting the electric consumption of objects using artificial neural networks // E3S Web of Conferences. $216 \quad 01170$. https://doi.org/10.1051/e3sconf/202021601170

8. I.Rakhmonov, A.Berdishev, B.Khusanov, U.Khaliknazarov, U.Utegenov. General characteristics of networks and features of electricity consumers in rural areas // CONMECHYDRO - 2020. IOP Conf. Series: Materials Science and Engineering. $883 \quad$ (2020) 012104. doi:10.1088/1757-899X/883/1/012104

9. R.Karimov, M.Bobojanov. Analysis of voltage stabilizers and non-contact relays in power supply systems // RSES 2020. E3S Web of Conferences. 216 (2020) 01162. https://doi.org/10.1051/e3sconf/202021601162 
10. R.Karimov. Study of the state of the issue of increasing the quality of electric energy in the power supply systems // RSES 2020. E3S Web of Conferences. 216 (2020) 01163. https://doi.org/10.1051/e3sconf/202021601163

11. I.U.Rakhmonov, A.N.Tovbaev, L.A.Nematov and T.Sh.Alibekova. Development of forecasted values of specific norms for the issues of produced products in industrial enterprises // ICMSIT-2020. Journal of Physics: Conference Series. 1515 (2020) 022050. doi:10.1088/1742 $6596 / 1515 / 2 / 022050$

12. I.U.Rakhmonov,

L.Nematov, K.M.Reymov, T.Yuldoshev. Power consumption management from the positions of the general system theory // ICMSIT-2020. Journal of Physics: Conference Series. 1515 (2020) 022054. doi:10.1088/1742-6596/1515/2/022054

13. I.U.Rakhmonov, F.A.Hoshimov. Development of an algorithm for evaluating the dominant factors that have the greatest impact on the energy intensity of products // ENERGY-21. E3S Web of Conferences. 209 (2020) 07018. https://doi.org/10.1051/e3sconf/202020907018

14. Usmanov E.G. Stability in a parallel resonant circuit with active load // RSES 2020. E3S Web of Conferences. 216 (2020) 01160. https://doi.org/10.1051/e3sconf/202021601160 15. Usmanov E.G., Khusanov B.M. Phase relations in resonant circuits with a wide falling section on the amplitude characteristic // RSES 2020. E3S Web of Conferences. 216 (2020) 01161. https://doi.org/10.1051/e3sconf/202021601161 16. I.U.Rakhmonov, K.M.Reymov and S.H.Dustova. Improvements in industrial energy rationing methods // MIP: Engineering-2020. E3S Web of Conferences. 862 (2020) 062070. doi:10.1088/1757-899X/862/6/062070

17. I.U.Rakhmonov, K.M.Reymov. Statistical models of renewable energy intermittency // RSES 2020. E3S Web of Conferences. $\quad 216 \quad$ (2020)

https://doi.org/10.1051/e3sconf/202021601167

18. I.U.Rakhmonov, N.N.Kurbonov. Analysis of automated software for monitoring energy consumption and efficiency of industrial enterprises // E3S Web of Conferences. 216 (2020) 01178. https://doi.org/10.1051/e3sconf/202021601178 19. F.A.Hoshimov, I.U.Rakhmonov, N.N.Niyozov. Technology to reduce energy costs in the electric steel melting shop // ENERGY-21. E3S Web of Conferences. 209 (2020) 07017. https://doi.org/10.1051/e3sconf/202020907017 20. A.Taslimov, F.Rakhimov, L.Nematov, N.Markaev, A.Bijanov, R.Yunusov. Economic load intervals for selecting $10 \mathrm{kV}$ cable cross-sections for agricultural consumers // CONMECHYDRO - 2020. IOP Conf. Series: Materials Science and Engineering. $883 \quad$ (2020) 012102. doi:10.1088/1757-899X/883/1/012102

21. A.Taslimov, M.Melikuziev, O.Matchonov, M.Ruzinazarov and M.Nasirov. Development of standard cable cross-sections of rural electrical networks // CONMECHYDRO - 2020. IOP Conf. Series: Materials Science and Engineering. $883 \quad$ (2020) 012105. doi:10.1088/1757-899X/883/1/012105

22. A.D.Taslimov, F.M.Rakhimov, A.O.Norkulov, A.A.Yuldashev. Research of the optimum scale of standard sections of agricultural purpose lines // E3S Web of Conferences. $216 \quad$ (2020)

https://doi.org/10.1051/e3sconf/202021601158

23. A.D.Taslimov., M.V.Melikuziev, A.M.Najimova, A.A.Alimov. Economic load intervals for selection of cable sections for agricultural purpose // E3S Web of Conferences. 216 (2020)

01159.

https://doi.org/10.1051/e3sconf/202021601159

24. Hadha Afrisal, Budi Setiyono, Muhammad Fahmi Yusuf, Rose Mutiara Suin, Olimjon Toirov 2020 7th International Conference on Information Technology, Computer, and Electrical Engineering (ICITACEE), pp. 4146 https://doi.org/10.1109/ICITACEE50144.2020.9239228 (2020),

25. Kamoliddin Alimkhodjaev, Olimjon Toirov, Mirzohid Taniev, Sharofiddin Alimkhodjaev Addressing Issues and Possibility of Introducing Renewable Energy Sources in the Conditions of Uzbekistan. JCR. 7(15), 1721-1728 (2020), doi:10.31838/jcr.07.15.231

26. Olimjon Toirov, Kamoliddin Alimkhodjaev, Akhror Pardaboev Analysis and ways of reducing electricity losses in the electric power systems of industrial enterprises, E3S Web of Conferences, SUSE-2021 (2021)

27. Abduazizov N.A., Muzaffarov A., Toshow J.B., Juraev R.U., Zhuraev A.Sh. A complex of methods for analyzing the working fluid of a hydrostatic power plant for hydraulic mining machines // International Journal of Advanced Science and Technology. Vol. 29, No. 5s, (2020), pp. 852855

28. Baratov B., Toshov J., Baynazov U. Method of calculating the gear ratios of the cones of tricone drill bits // E3S Web Conf., Volume 201, 01012, 2020, Ukrainian School of Mining Engineering - 2020. https://doi.org/10.1051/e3sconf/202020101012

29. Haqberdiev A., Toshov J. Analysis of the control system of electric motors of the running gear of self-propelled mine cars used in complex mining and technological conditions // E3S Web of Conferences 216, 01135 (2020), Rudenko International Conference "Methodological problems in reliability study of large energy systems" (RSES 2020), https://doi.org/10.1051/e3sconf/202021601135

30. K.M.Reymov, G.Turmanova, S.Makhmuthonov, B.Uzakov. Mathematical models and algorithms of optimal load management of electrical consumers // E3S Web of $\begin{array}{lll}\text { Conf. } & 216 & \text { (2020) }\end{array}$ https://doi.org/10.1051/e3sconf/202021601166

31. Yu.M.Bobozhonov, K.M.Reymov, B.T.Seytmuratov, T.Kh.Khakimov. Research of the dependence of the resistance of asynchronous generators with massive rotors on their design // RSES 2020. E3S Web of Conferences. 216 (2020) 01168. https://doi.org/10.1051/e3sconf/202021601168 32. Rakhmonov I U, Reymov K M, Najimova A M, Uzakov B T and Seytmuratov BT 2019 Analysis and calculation of optimum parameters of electric arc furnace Journal of Physics: Conference Series 1399 doi:10.1088/17426596/1399/5/055048

33. Toshniyozov L.G., Toshov J.B. Theoretical and experimental research into process of packing in drilling. MIAB. Mining Inf. Anal. Bull. 2019;(11):139-151. [In Russ]. DOI: 10.25018/0236-1493-2019-11-0-139-151.

34. Toshov J.B. The questions of the dynamics of drilling bit on the surface of well bottom// Arch. Min. Sci. - Poland. Vol. 61 (2016), № 2, P. 279-287. DOI 10.1515/amsc-20160020

35. Toshov Zh.B. Ways towards optimization of washout components of rock cutting tools // «GORNYI 
ZHURNAL»/《MINING JOURNAL», Moscow, 2016, № 2, pp. 21-24. DOI: http://dx.doi.org/10.17580/gzh.

36. A.N.Rasulov, M.R.Ruzinazarov, N.Toirova, T.Sh.Alibekova. Graphical-analytical method for constructing load characteristics // RSES 2020. E3S Web of
Conferences.
216
(2020)
01171.

https://doi.org/10.1051/e3sconf/202021601171

37. Yu.Bobozhonov, B.Seytmuratov, B.Fayzullaev, A.Sultonov. Study of the influence of different designs of massive rotor of asynchronous generator on their maximum power // RSES 2020. E3S Web of Conferences. 216 (2020) 01177. https://doi.org/10.1051/e3sconf/202021601177

38. Taslimov A D, Rakhmonov I U 2019 Optimization of complex parameters of urban distribution electric networks Journal of Physics: Conference Series 1399 doi:10.1088/1742-6596/1399/5/055046

39. Rakhmonov I U, Niyozov N N 2019 Optimization setting of steel-smelting industry in the issue of alloy steels E3S Web Conf 139 doi:10.1051/e3sconf/201913901077

40. Rakhmonov I U, Reymov K M and Shayumova Z M 2019 The role information in power management tasks. E3S Web Conf 139 doi:10.1051/e3sconf/201913901080 